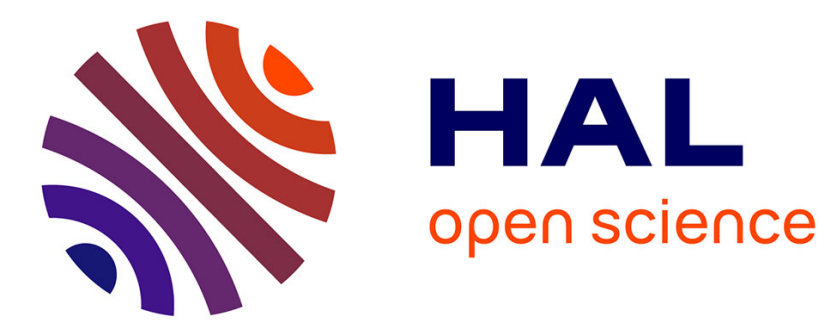

\title{
Book Review: Retention and Student Success in Higher Education
}

Kehinde Oduyemi

\section{To cite this version:}

Kehinde Oduyemi. Book Review: Retention and Student Success in Higher Education. Active Learning in Higher Education, 2006, 7 (1), pp.102-103. 10.1177/146978740600700110 . hal-00571938

\section{HAL Id: hal-00571938 \\ https://hal.science/hal-00571938}

Submitted on 1 Mar 2011

HAL is a multi-disciplinary open access archive for the deposit and dissemination of scientific research documents, whether they are published or not. The documents may come from teaching and research institutions in France or abroad, or from public or private research centers.
L'archive ouverte pluridisciplinaire HAL, est destinée au dépôt et à la diffusion de documents scientifiques de niveau recherche, publiés ou non, émanant des établissements d'enseignement et de recherche français ou étrangers, des laboratoires publics ou privés. 
The chapters in Part Three (Enhancing Student Progression) address reflective practices and how they can influence a student's progression in HE. Jenny Moon explores learning as represented in level descriptors, Jenny Phillips describes the development of the Keynote Guide to PDP, and Kathryn McFarlane's chapter on Learning about Employability completes the set of three topics that are a priority for many tutors in HE. All the authors offer excellent advice to readers wishing to incorporate the strategies discussed in the chapters into their courses or research projects.

The chapters in Part Four (Supporting and Developing Staff) shift the focus from students to the support and development of staff. John Shaw claims that it is important for those who support learning to understand how they learn in order to improve their teaching. He challenges the reader to instigate an action research project addressing an educational hypothesis, engaging in reflection and acting on the findings. Vivien Sieber's chapter on Learning to Teach with Technology is excellent, highlighting the important skills required and some strategies that promote the development of these skills. Each section ends with key questions and challenges for the tutor, to aid the development of their teaching with technology. The final two chapters address the impact of new legislation and policy changes on inclusive learning and equality of opportunity. Both authors make it very clear that the new legislation involves everyone in $\mathrm{HE}$ and offer excellent guidance for implementation.

This book does what it sets out to do in that it considers at the operational level a range of new approaches for improving students' learning and will be useful and challenging for a wide range of tutors in HE. In particular, the examples of pedagogic research will be extremely helpful to tutors who are participating in Higher Education Academy Accredited Postgraduate Certificate courses and will complement the core texts that already exist.

DERRY COREY

College of St Mark \& St John, Plymouth

Retention and Student Success in Higher Education by Mantz Yorke and Bernard Longden. London: The Society for Research into Higher Education \& Open University Press, 2004. ISBN 0-3352-1274-3. 171 pp. $£ 23.99$ (pbk).

This book is concerned with many aspects of retention and student success in higher education systems, covering:

retention and student success from a public policy perspective; the theoretical approaches and enhancement measures for retention.

All ten chapters of the book have been written in a professional manner, with its presentation, analysis and discussion based upon a wide range of sources of information. A welcome feature is the international perspective, particularly from the UK, Australia, South Africa and the United States. 
The book comprises two main parts. The first five chapters are primarily on the subject of higher education systems and their performance. The latter five chapters focus on how institutions can help to increase the chances of student success. The main benefit of this book is in the information gathered and reviewed, which would be useful to both researchers into higher education and educators who want to enhance retention and student success practices in higher education. I particularly enjoyed reading all the chapters in the book, but those who are seeking ideas and innovative approaches that they could implement in their institutions would probably want to focus on the latter three chapters.

Chapters 6 and 7 discuss and draw together the theory relating to retention and student success. These two chapters, together with the high level of relevant citations, should be a useful resource for researchers in the field of 'student departure and retention in higher education', as they allow for reflection on how to refine and extend the theoretical approaches. The authors advanced the argument that, 'whilst much of the theorizing about retention reflects sociological concerns, students' decision-making whether to persist or withdraw is fundamentally a matter of psychology'. It is arguable that students' perception of their experience in higher education is influenced by many factors, including sociological and psychological factors. The authors suggest, quite rightly in my experience, that some of the factors are beyond the powers of an institution of learning to influence - hence the suggestion by the authors that existing theoretical approaches relating to retention and student success need refinement and extension. The authors acknowledge that while the suggestions made in the final chapter have a broad applicability within higher education, some are likely to need adjustment to suit individual institutions and particular national systems.

The book contains a large number of excellent illustrations, which have been used to great effect in assisting the understanding of the texts in the book. The citations, list of references, endnotes, author index and subject index are sufficiently comprehensive to help the reader. One list of references is provided at the end of the book, and I would have preferred to see a list of references at the end of each chapter.

The book is well structured and the fonts used in the book should find favour with the reader. The use of case studies and research evidence is particularly welcomed.

In summary, this is a high-quality publication. It is an enjoyable read and a valuable information source. The book should serve as a very good resource for practitioners in higher education institutions, including lecturers, support staff and senior managers. The book is also likely to provide an interesting read for politicians and civil servants with wider policy interest in higher education matters. The publication achieves its objective and has many references for reader to obtain more detail if required. 